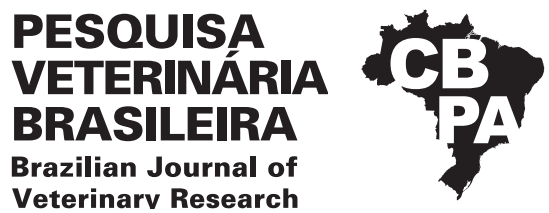

Pesq. Vet. Bras. 40(7):525-535, July 2020 DOI: 10.1590/1678-5150-PVB-6615

Original Article

inarv Research

Small Animal Diseases

ISSN 0100-736X (Print)

ISSN 1678-5150 (Online)

\title{
Testicular tumors in 190 dogs: clinical, macroscopic and histopathological aspects ${ }^{1}$
}

\author{
Harlan H.L. Nascimento ${ }^{2}$, Alex dos Santos ${ }^{2}$, Amanda L. Prante ${ }^{3}$, Eryca C. Lamego ${ }^{3}$, \\ Luís A.S. Tondo ${ }^{3}$, Mariana M. Flores ${ }^{4}$ (D) Rafael A. Fighera ${ }^{4}$ (D) \\ and Glaucia D. Kommers ${ }^{4 *}$ (D)
}

\begin{abstract}
Nascimento H.H.L., Santos A., Prante A.L., Lamego E.C., Tondo L.A.S., Flores M.M., Fighera R.A. \& Kommers G.D. 2020. Testicular tumors in 190 dogs: clinical, macroscopic and histopathogical aspects. Pesquisa Veterinária Brasileira 40(7):525-535. Laboratório de Patologia Veterinária, Departamento de Patologia, Universidade Federal de Santa Maria, Camobi, Santa Maria, RS 97105-900, Brazil. E-mail: glaukommers@yahoo.com

This study aimed to characterize the prevalence and clinical, macroscopic and histopathological aspects of dogs affected by testicular tumors based on biopsy specimens from the Laboratório de Patologia Veterinária of the Universidade Federal de Santa Maria (LPV-UFSM) over 19 years. Parameters regarding the age, size, and breed of the affected dogs were also established. Of all dogs with some type of neoplasm submitted to histopathological analysis at the LPV over these 19 years $(n=1,900), 213(11.2 \%)$ had at least one testicular neoplasm. The tissues of 190 dogs (with 220 neoplasms) were available for histological reassessment. The dogs in this study had different types of testicular tumors with relatively similar frequencies. In descending order, the most frequent testicular neoplasms were seminomas (88/220), Leydig (interstitial) cell tumor (LCT; 64/220), Sertoli cell tumor (SCT; 61/220), and mixed germ cell-sex cord stromal tumor (MGSCT) $(07 / 220)$. Among the dogs of defined breed (119 cases), large breeds had the largest number of cases (50/119), followed by small $(47 / 119)$ and medium-sized (22/119) breeds. The ages of dogs affected by testicular tumors ranged from 10 months to 18 years. Increased testicular volume was the most common clinical manifestation. Eleven dogs presented information about clinical signs suggestive of hyperestrogenism syndrome (feminization). In seminomas, the diffuse pattern predominated over the intratubular pattern. Two sites (luminal and basal compartments) suggestive of the onset of neoplastic transformations in germ cells were observed in intratubular seminomas. They corroborate the hypothesis that canine seminomas possibly have pathogenesis similar to that observed in human spermatocytic seminomas. The SCTs and LCTs presented high cell morphology variation. SCTs had neoplastic cells organized in five different histological arrangements. As for LCT, solid-diffuse and cystic-vascular histological patterns were the most commonly observed. Through this study, it was possible to establish some of the leading clinical, macroscopic, and histopathological aspects of testicular neoplasms diagnosed over 19 years in the area covered by the LPV-UFSM.
\end{abstract}

INDEX TERMS: Testicular tumors, dogs, clinics, macroscopy, histopathology, testicular neoplasms, clinical aspects, morphology.

\footnotetext{
${ }^{1}$ Received on March 3, 2020.

Accepted for publication March 16, 2020.

Part of the Doctoral Dissertation of the first author.

${ }^{2}$ Graduate Program in Veterinary Medicine with emphasis in Pathology and Veterinary Clinical Pathology, Centro de Ciência Rurais (CCR), Universidade Federal de Santa Maria (UFSM), Av. Roraima 1000, Camobi, Santa Maria, RS 97105-900, Brazil.
}

\footnotetext{
${ }^{3}$ Curso de Medicina Veterinária, Centro de Ciência Rurais (CCR), Universidade Federal de Santa Maria (UFSM), Av. Roraima 1000, Camobi, Santa Maria, RS 97105-900, Brazil.

${ }^{4}$ Laboratório de Patologia Veterinária, Departamento de Patologia, Centro de Ciências da Saúde, Universidade Federal de Santa Maria (UFSM), Av. Roraima 1000, Camobi, Santa Maria, RS 97105-900, Brazil. *Corresponding author: glaukommers@yahoo.com
} 
RESUMO.- [Neoplasmas testiculares em 190 cães: aspectos clínicos, macroscópicos e histopatológicos.] Este estudo teve por objetivo caracterizar a prevalência, aspectos clínicos, macroscópicos e histopatológicos dos cães acometidos por neoplasmas testiculares, a partir dos espécimes de biópsias do Laboratório de Patologia Veterinária da Universidade Federal de Santa Maria (LPV-UFSM) em 19 anos. Parâmetros quanto à idade, porte, raça dos cães acometidos também foram estabelecidos. De todos os cães com algum tipo de neoplasma submetido à análise histopatológica no LPV nesses 19 anos (n=1.900), $213(11,2 \%)$ tinham ao menos um neoplasma testicular. Os tecidos de 190 cães (com 220 neoplasmas) estavam disponíveis para reavaliação histológica. Os cães deste estudo apresentaram diferentes tipos de neoplasmas testiculares com frequências relativamente semelhantes. Em ordem decrescente, os neoplasmas testiculares mais frequentes foram: seminomas (88/220), leydigomas (64/220), sertoliomas (61/220) e o tumor misto de células germinativas e do estroma do cordão sexual (MGSCT; 07/220). Dentre os cães com raça definida (119 casos), as raças de grande porte tiveram o maior número de casos $(50 / 119)$, seguido das raças de pequeno $(47 / 119)$ e médio porte $(22 / 119)$. As idades dos cães acometidos por neoplasmas testiculares variaram de 10 meses a 18 anos. Aumento de volume testicular foi a manifestação clínica mais comum. Onze cães tinham informações sobre sinais clínicos sugestivos da síndrome da feminilização. Nos seminomas, houve o predomínio do padrão difuso sobre o intratubular. Dois locais (compartimentos luminal e basal) sugestivos de início das transformações neoplásicas nas células germinativas foram observados nos seminomas intratubulares, corroborando com a hipótese de que os seminomas caninos possivelmente tem patogênese semelhante à observada nos seminomas espermatocíticos humanos. Sertoliomas e leydigomas foram neoplasmas com alta variação na morfologia celular. Os sertoliomas tinham células neoplásicas dispostas em cinco arranjos histológicos distintos. Quanto aos leydigomas, os padrões histológicos sólido-difuso e cístico-vascular foram os mais comumente observados. Através deste estudo foi possível estabelecer alguns dos principais aspectos clínicos, macroscópicos e histopatológicos dos neoplasmas testiculares diagnosticados em 19 anos na área de abrangência do LPV-UFSM.

TERMOS DE INDEXAÇÃO: Tumores testiculares, cães, clínica, macroscopia, histopatologia, caninos, neoplasmas testiculares, aspectos clínicos, morfologia.

\section{INTRODUCTION}

Epidemiological studies point to testicular neoplasms as the most common tumors of the genital tract of male dogs (Cotchin 1960, Hayes \& Pendergrass, 1976, Sapierzyński et al. 2007). In these studies, the most commonly diagnosed neoplasm types were germ cell (seminomas) and sex cord stromal (Sertoli cell and Leydig cell) tumors. The most relevant associated clinical aspects include expansive growth with marked distension of the affected testicles and clinical syndromes. Some authors point to cryptorchidism as a risk factor for these neoplasms (Hayes \& Pendergrass 1976, Madewell 1981, Hayes et al. 1985, Yates et al. 2003, OrtegaPacheco et al. 2006). However, other described factors less provenly associated include breed predisposition, inguinal hernias, and action of therapeutic agents and herbicides (Hayes et al. 1985, 1990, Kesley et al. 1998).

The histopathological patterns of these neoplasms have long been known (Nielsen \& Lein 1974, Maclachlan \& Kennedy 2002); however, some tumors are infrequent, difficult to diagnose, and have poorly described histological peculiarities (Patnaik \& Mostofi 1993, Reis-Filho et al. 2004). Thus, retrospective studies including the reevaluation of cases can be useful in establishing prevalence in dogs, characterizing factors associated with the occurrence of these tumors, and describing unusual histological peculiarities that may present diagnostic relevance in understanding the pathogenesis of testicular neoplasms. The present study aimed to characterize the breeds, breed sizes and ages of the affected dogs, as well as prevalence and clinical, macroscopic and histopathological aspects of canine testicular neoplasms through a retrospective survey of the biopsy protocols of the Laboratório de Patologia Veterinária of the Universidade Federal de Santa Maria (LPVUFSM) in 19 years (2000-2018).

\section{MATERIALS AND METHODS}

Data on the breeds, ages, and clinical signs of the affected dogs and on the gross aspects of the neoplasms were obtained from the report files of the LPV-UFSM over 19 years (2000-2018). These data were accessed from biopsy specimens of male dogs received by the laboratory during this period. Of the total cases, dogs with testicular neoplasms were counted, as well as the total number of neoplasms diagnosed in different organs in these dogs.

Breeds were grouped according to size: small (breeds up to $10 \mathrm{~kg}$ ), medium-sized (between $11-20 \mathrm{~kg}$ ) and large (over $20 \mathrm{~kg}$ ). Giant breeds were included in the last category (adapted from Folge 2009). Dogs of defined breed size were divided into four age groups (young, adults, seniors, and geriatric), shown in Table 1. Due to lack of information on weight in the biopsy protocols, mixedbreed dogs with no established breed size were not grouped in the size categories previously described. Consequently, they were not subdivided into age groups.

As for clinical manifestations, dogs with a history of increased testicular or scrotal volume, pain on palpation, cryptorchidism, inguinal hernias, and occurrence of clinical syndromes (feminization) were counted. The gross aspects were reviewed based on presentation of the neoplasms (nodules or masses), in the distribution (single/focal or multiple/multifocal neoplasms), and regarding consistency, color, and secondary aspects (presence of hemorrhage, necrosis, and cysts). The concepts of nodule and mass were adapted as already described (Gould et al. 2007). Tumors $\leq 3.0 \mathrm{~cm}$ in diameter were considered as nodules, whereas those $>3.0 \mathrm{~cm}$ were considered as masses.

For histopathological reassessment, new slides of previously diagnosed testicular neoplasms were prepared. The tissue samples were cut into $3.0 \mu \mathrm{m}$ sections, stained with hematoxylin and eosin (HE), reassessed, and reclassified according to the histological

Table 1. Distribution of dogs of defined breed according to age group

\begin{tabular}{lcccc}
\hline \multicolumn{1}{c}{ Breed size } & Young & Adults & Seniors & Geriatric \\
\hline Small & 1-3 years & 4-8 years & 9-13 years & $>13$ years \\
Medium & 1-2 years & 3-8 years & 9-11 years & $>11$ years \\
Large & 1-2 years & 3-5 years & 6-9 years & $>$ y years
\end{tabular}

Adapted from Folge (2009) and Gardner (2017). 
classification of genital tract tumors in domestic animals of the World Health Organization (WHO) (Kennedy et al. 1998). When applicable, tumors with morphological peculiarities suggestive of specific types were assessed by histochemical techniques in order to improve the analysis of these aspects.

\section{RESULTS}

\section{Prevalence of affected dogs and frequency of testicular neoplasms}

During the study period (2000-2018), 3,323 cases of biopsies in male dogs were recorded. Of these dogs submitted to biopsies, 1,900 had one or more neoplasm diagnoses, accounting for 2,118 neoplasms in different organs. The prevalence of dogs with testicular neoplasms was 213/1,900 cases, corresponding to $11.2 \%$ of all dogs affected by neoplasms. Of these 213 dogs, 190 had paraffin blocks available for histopathological reassessment. Considering that these 190 dogs had more than one testicular neoplasm, 220 neoplasms were diagnosed. In descending order, the most common testicular neoplasms in the diagnostic routine were seminomas $(88 / 220,40 \%)$, Leydig cell tumors (LCT; 64/220, 29.1\%), Sertoli cell tumors (SCT; 61/220, 27.7\%), and mixed germ cell-sex cord stromal tumors (MGSCT; 07/220, 3.2\%).

More than one type of testicular neoplasm was diagnosed in 30 of the 190 dogs (15.8\%). Sixteen had different neoplasms confined to the same testis. In $10 \mathrm{dogs}$, both testicles were affected. In the other four cases, different tumors affected both testicles. The most common combination of neoplasms was seminoma and LCT, observed in 16 dogs, followed by seminoma and SCT (12/190), and SCT and LCT (2/190).

\section{Breed and age characterization}

Of the 190 reassessed cases, 119 dogs were distributed in 25 breeds, 60/190 were mixed-breed, and information on breed was not obtained in 11/190. Large breeds accounted for the largest number of cases $(50 / 119)$, followed by small (47/119) and medium-sized (22/119) breeds. In descending order, the most affected breeds were Poodle (22/119), Cocker Spaniel (16/119), Boxer (12/119), German Shepherd (11/119), Pinscher (09/119), Dachshund (7/119), Labrador Retriever (7/119), Collie (5/119), and Yorkshire Terrier (4/119).

Age of the 190 dogs affected by testicular neoplasms ranged from 10 months to 18 years. Among the dogs of defined breed size, seniors and geriatric accounted for most cases, while a smaller proportion were adult and young animals (Fig.1). Only small dogs had neoplasms distributed throughout the four age groups. In this category, senior dogs were the most affected. In medium-sized breeds, most tumors were observed in the age group $>8$ years, including senior and geriatric dogs. Among large dogs, the geriatric group was the most affected, and presented a significant number of cases compared with those of other age groups. Figure 2 shows the number of dogs affected by testicular neoplasms in the four age groups according to the three categories of breed size. In 7/190 dogs, including three defined breed dogs, information about age was not available. Mean age by tumor type was 10.8 years for seminomas (range from 10 months to 15 years), 10.6 years for SCT ( 4 to 18 years), 11.2 for LCT (2 to 17 years), and 12.4 years for MGSCT ( 6 to 15 years). In dogs diagnosed with more than one type of neoplasm, the mean age was 10.5 years (range from 5 to 15 years).

\section{Clinical aspects}

Increased testicular volume was the most common clinical manifestation, reported in 92 (48.4\%) of the 190 dogs. Increased scrotal volume (thickening of the skin) and pain on palpation were reported in 14/190 (7.4\%) and 6/190 (3.2\%) cases, respectively. In eleven dogs (5.8\%), information in the biopsy protocols showed manifestation of clinical signs suggestive of feminization (hyperestrogenism syndrome). Of these, 4/11 had gynecomastia and 4/11 developed skin lesions characterized by alopecia, thickening and hyperpigmentation, being generally bilaterally symmetrical in the regions of the abdomen, thorax, and limbs. In the other $3 / 11$, both changes previously described (gynecomastia and skin lesions) were reported. SCT were diagnosed in 7/11 dogs, three were affected by seminoma-SCT combination, and one had MGSCT.

Fifty-one $(23.2 \%)$ of the 220 neoplasms were observed in $43(22.6 \%)$ cryptorchid dogs. Seminoma was the most frequent tumor among cryptorchid dogs $(15 / 43)$, followed by SCT with 13/43 cases. A smaller proportion of dogs with cryptorchidism had combinations of neoplasms (8/43), as well as LCT (4/43) and MGSCT (3/43). Table 2 shows the location of the ectopic testicles according to neoplasm type. Hernias were reported in three dogs, with two perineal cases and one inguinoscrotal case.

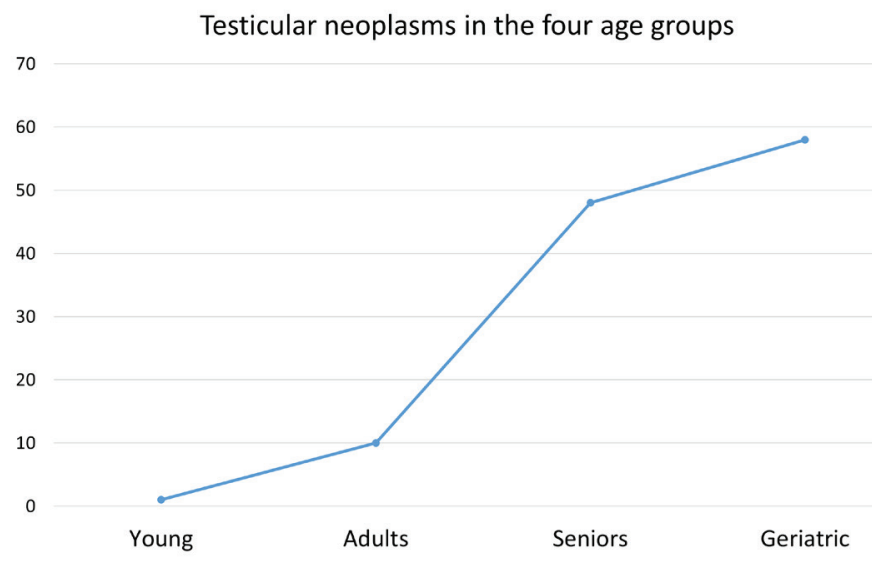

Fig.1. Distribution of testicular neoplasms in the four age groups.

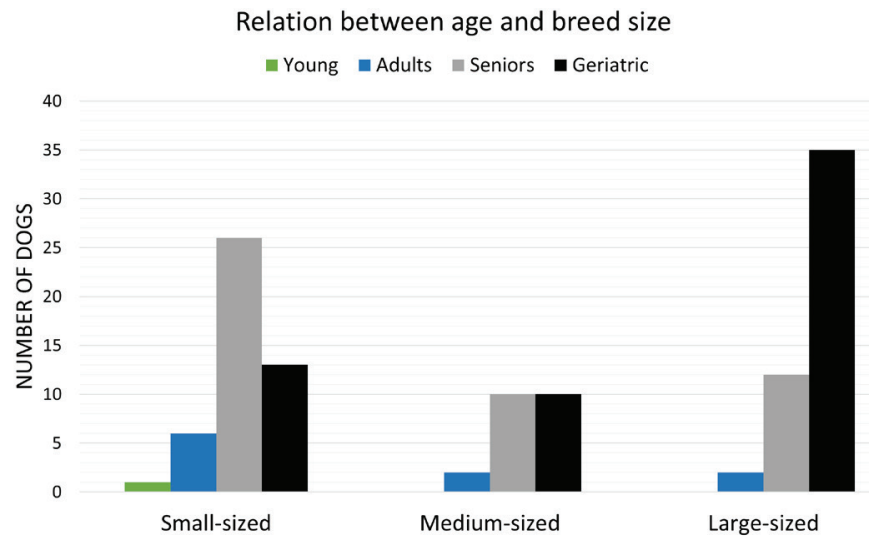

Fig.2. Dogs affected by testicular neoplasms in the four age groups according to the three breed size categories. 
Table 2. Location of cryptorchidic testicles by type of neoplasm

\begin{tabular}{lcccc}
\hline $\begin{array}{c}\text { Tumor } \\
\text { type or } \\
\text { combination }\end{array}$ & $\begin{array}{c}\text { Inguinal } \\
\text { cryptorchid }\end{array}$ & $\begin{array}{c}\text { Abdominal } \\
\text { cryptorchid }\end{array}$ & Uninformed & $\begin{array}{c}\text { Number of } \\
\text { dogs }\end{array}$ \\
\hline Seminoma & 4 & 3 & 8 & 15 \\
SCT & 4 & - & 9 & 13 \\
LCT & 2 & 2 & $*$ & 4 \\
MGSCT & 2 & - & 1 & 3 \\
Sem-SCT & 2 & - & 5 & 7 \\
Sem-LCT & 1 & $*$ & $*$ & 1 \\
TOTAL & 15 & 5 & 23 & 43 \\
\hline
\end{tabular}

- Missing information; ${ }^{*}$ without occurrence; SCT = Sertoli cell tumor; LCT = Leydig cell tumor; Sem-SCT $=$ Seminoma-SCT combination, Sem-LCT = Seminoma-LCT combination, MGSCT = mixed germ cell-sex cord stromal tumor.

\section{Macroscopic and histopathological aspects}

Macroscopic and histopathological aspects are described according to decreasing sequence in dogs affected by a single type of neoplasm $(n=160)$.

\section{Seminomas $(n=60)$}

Most neoplasms (18/60) occurred as masses that were 5.0 to $10.0 \mathrm{~cm}$ long, soft or firm, reddish-white, with areas of hemorrhage and, sometimes, completely obliterating the testicular parenchyma (Fig.3). Single or multiple nodules corresponded to $16 / 60$ of the neoplasm cases, ranged from 0.4 to $3.0 \mathrm{~cm}$ in length, and were generally soft, white or yellow, with areas of hemorrhage. In 9/60 dogs, no gross changes were found, and the neoplasms were diagnosed histologically. Fourteen of the 60 seminomas presented an intratubular pattern, $41 / 60$ were diffuse, and both patterns were observed in 5/60 cases. Diffuse tumors were composed of sheets of neoplastic germ cells delineated by scarce fibrovascular stroma (Fig.4). The cells were round or polygonal and had moderate and eosinophilic cytoplasm. Their nuclei had vesicular or finely dotted chromatin and conspicuous nucleoli. Mitoses were frequent. Perivascular lymphocyte infiltrates, individual cell necrosis, and macrophages with vacuolated cytoplasm were common findings in diffuse seminomas.

As for intratubular seminomas, most tumors completely obliterated the lumens of the seminiferous tubules. However, in some cases, it was possible to detect two sites suggestive of neoplastic transformations. In the first and most common, the tumor cells were located in the center (luminal compartment) of the seminiferous tubules and were generally peripherally delineated by germ cells (round spermatids, spermatocytes, and spermatogonia) and stromal cells (Sertoli), with no evidence of neoplastic transformations (Fig.5). In the second pattern of localization of possible neoplastic transformations, one or two layers of neoplastic cells were observed in juxtaposition to the basement membrane (basal compartment). They had no remnants of germ or stromal components in the tubular lumen (Fig.6). Neoplastic cells with a syncytial aspect were an uncommon finding in some intratubular seminomas (Fig.7). These were fused, had more than ten nuclei, and were juxtaposed to the basement membrane. Six of the 60 seminomas were malignant. Infiltration of neoplastic cells into the lumen of blood and lymphatic vessels was observed

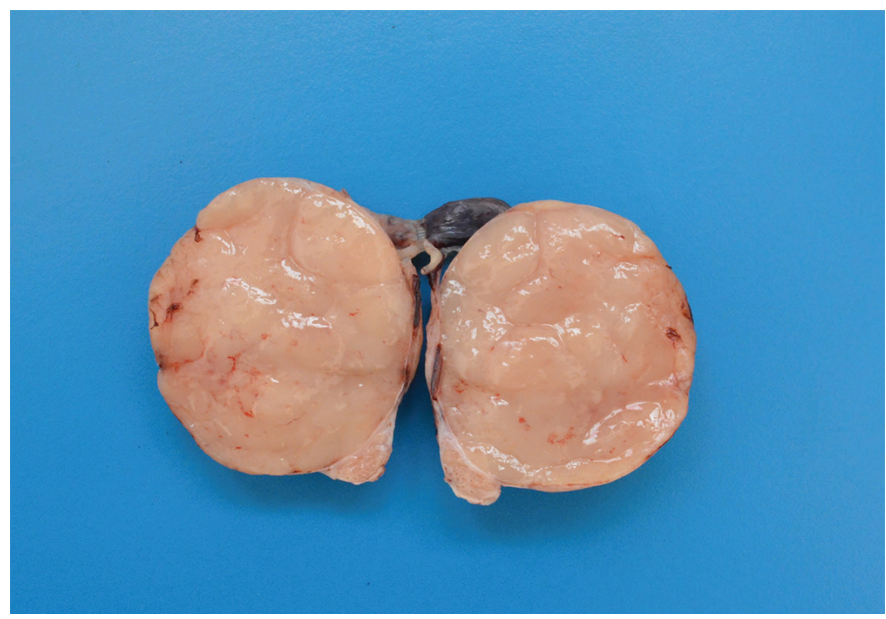

Fig.3. Seminoma. Testicular parenchyma obliterated by a white, soft mass with small areas of hemorrhage.

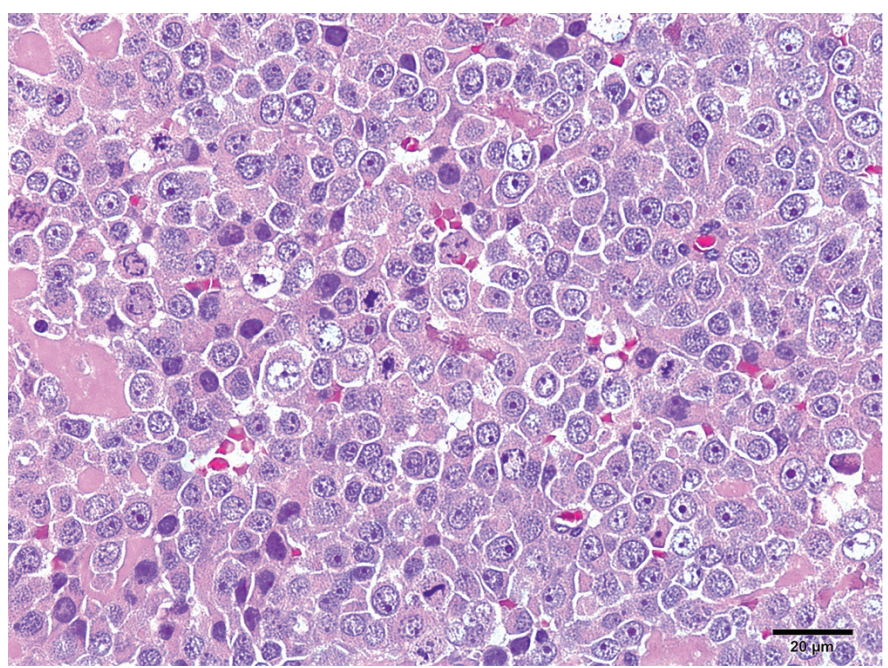

Fig.4. Diffuse seminoma. Marked anisocytosis, anisocariosis, and a high mitotic index were a marked aspect in diffuse seminoma. HE, obj.40x.

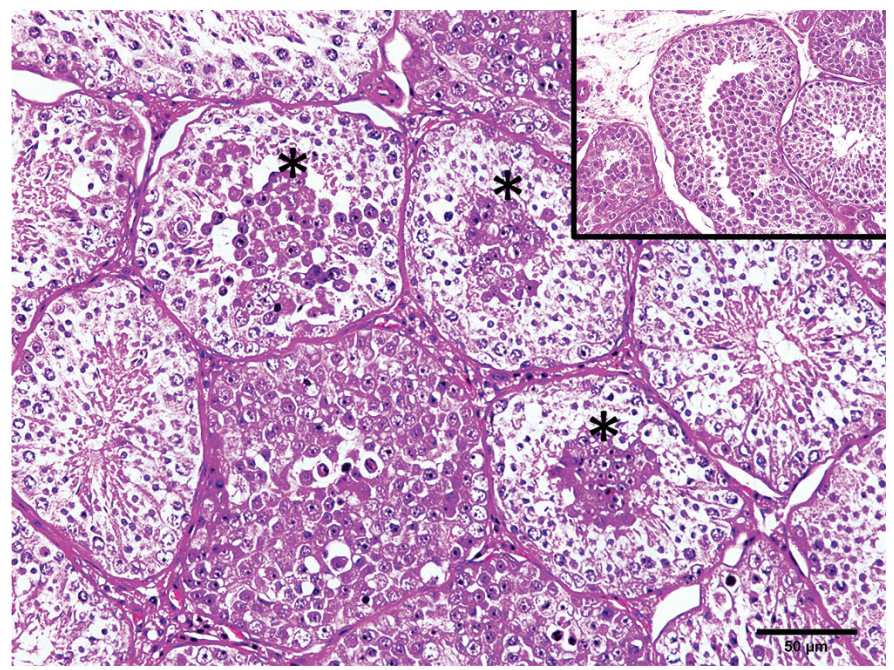

Fig.5. Intratubular seminoma. Neoplastic germ cells in the center of seminiferous tubules (asterisks), outlined by germinal epithelium with no evidence of neoplastic transformations (insert). HE, obj.20x. 
in 3/60 dogs. Three of the 60 dogs had metastases to regional lymph nodes and infiltration of adjacent testicular structures (tunica albuginea and epididymis).

\section{Sertoli cell tumors (SCT, $\mathrm{n}=47$ )}

Most SCT (16/47) occurred as nodules. These were 0.4 to $3.0 \mathrm{~cm}$ in diameter. In most cases they were firm and white. The larger neoplasms $(\mathrm{n}=12)$ usually formed single masses ranging from 4.0 to $11 \mathrm{~cm}$ in length (Fig.8). When cut, they were firm or soft and had a white, multilobed, friable cut surface with areas of hemorrhage. Presence of cystic formations was a relatively frequent finding, regardless of the gross presentation and size of SCTs. These formations were single or multiple and filled with brown gelatinous content or blood.

Under microscopy, 24/47 sertoliomas had an intratubular pattern, $9 / 47$ presented a diffuse pattern, and both patterns were observed in 14/47 cases. Among the neoplasms reassessed in this survey, SCTs presented the most significant heterogeneity regarding cell pleomorphism. Moderate to

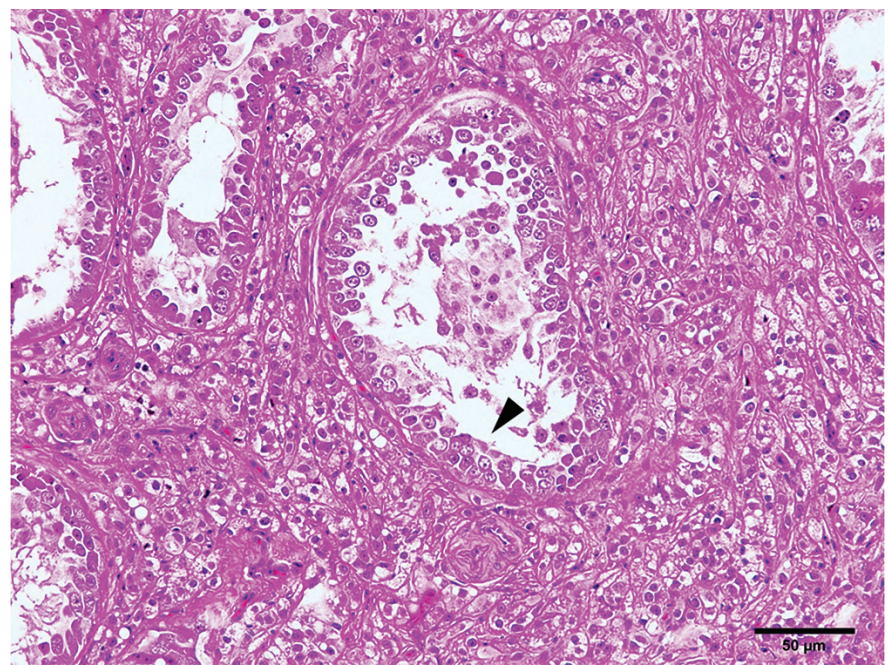

Fig.6. Intratubular seminoma. Germ cells juxtaposed to the basement membrane (arrowhead), with no stromal cell remnants (Sertoli) in the tubular lumen. HE, obj.20x.

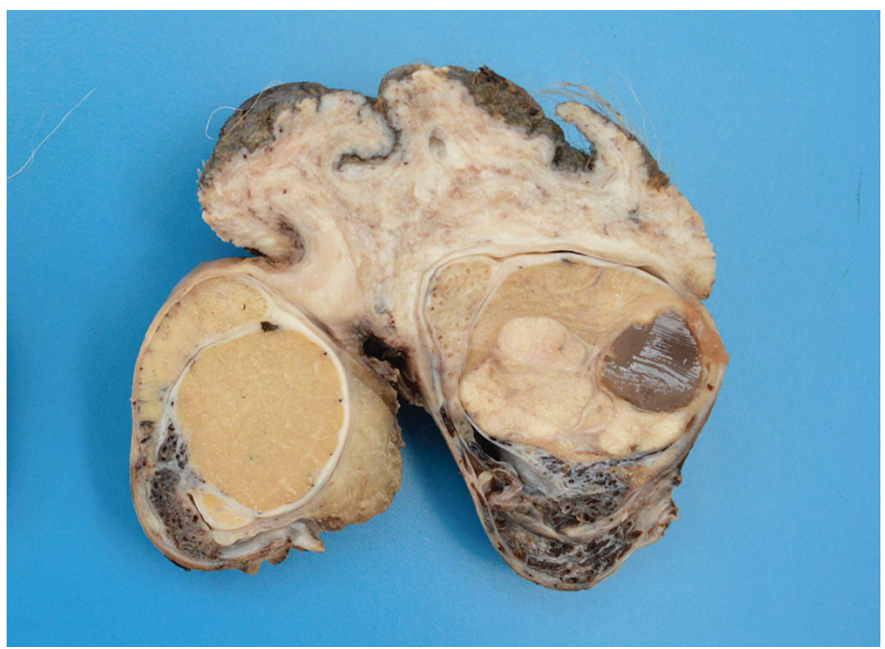

Fig.8. Sertoli cell tumor. White, firm mass, partially obliterating the testicular parenchyma. Cystic formation filled with brown gelatinous content is observed adjacent to the neoplastic mass. severe desmoplastic reaction and hyalinization of seminiferous tubules were striking and characteristic aspects in the vast majority of SCTs. Presence of central areas of necrosis outlined by neoplastic Sertoli cells was another characteristic finding, especially in higher cell density proliferations. Neoplastic cells were organized in five distinct histological arrangements and some tumors presented more than one cellular arrangement at times. The five histological arrangements observed in SCTs are as follows:

a) Small cell tumors, usually polyhedral, with little distinct cell boundaries, and small, hyperchromatic nuclei. In this arrangement, SCTs had expansive growth, with distention and rupture of the tubular membrane, as well as areas of hemorrhage and necrosis contiguous with the neoplastic formations (Fig.9);

b) SCTs with neoplastic cells grouped in tubules of different sizes, sometimes with disruption of the

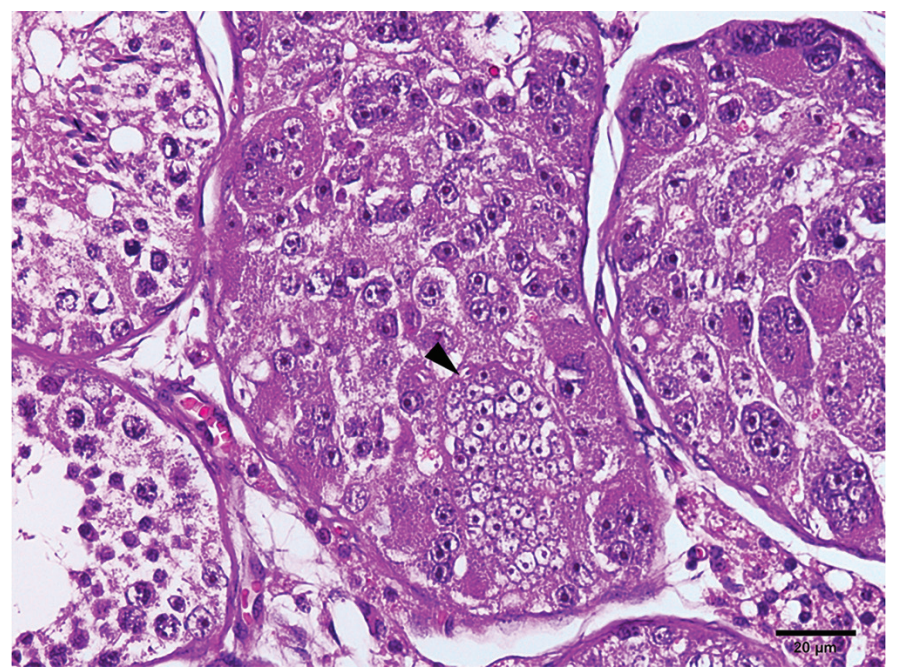

Fig.7. Intratubular seminoma. Seminiferous tubule obliterated by neoplastic germ cells. Syncytial cell juxtaposed to the basal membrane (arrowhead). HE, obj.40x.

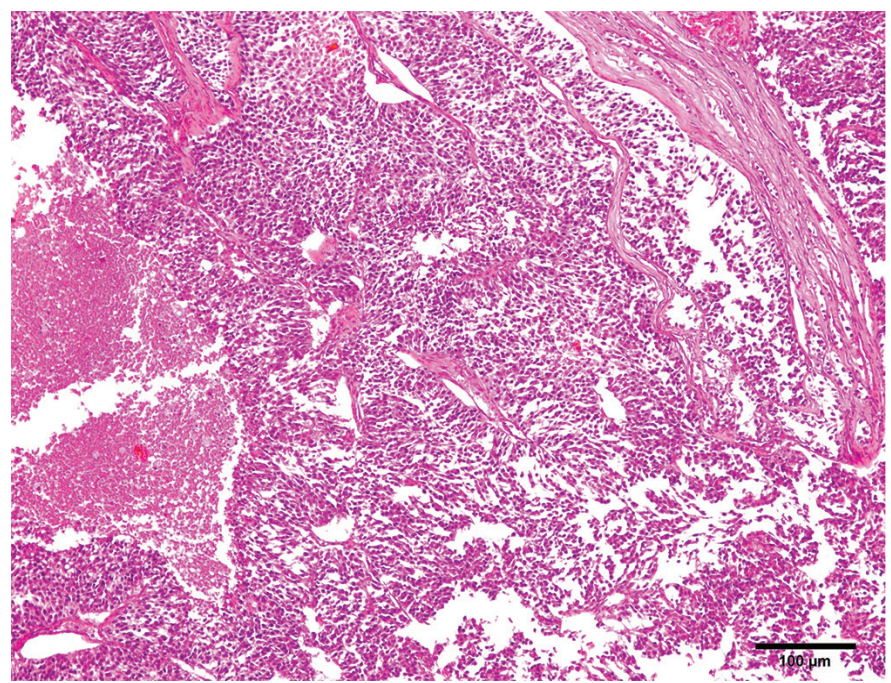

Fig.9. Diffuse Sertoli cell tumor. Neoplastic cells with expansive growth and rupture of the tubular basement membrane. HE, obj.10x. 
basement membrane. The cells had scarce cytoplasm, indistinct boundaries, and round nuclei with sparse and hypochromatic chromatin (Fig.10). Hemorrhage and necrosis of Sertoli and germ cells in the center of these formations were frequent, especially in larger proliferations;

c) Neoplasms with columnar cells of indistinct cell boundaries, slightly vacuolated, with nuclei in different positions were observed in palisades and free in the lumens of the tubules (Fig.11). In this arrangement, cells were confined to tubules of different sizes, sometimes with disruption of the basement membrane;

d) SCTs with entirely fusiform cells had abundant eosinophilic cytoplasm and moderately distinct cell limits (Fig.12). Their nuclei were spindle-shaped with sparse and

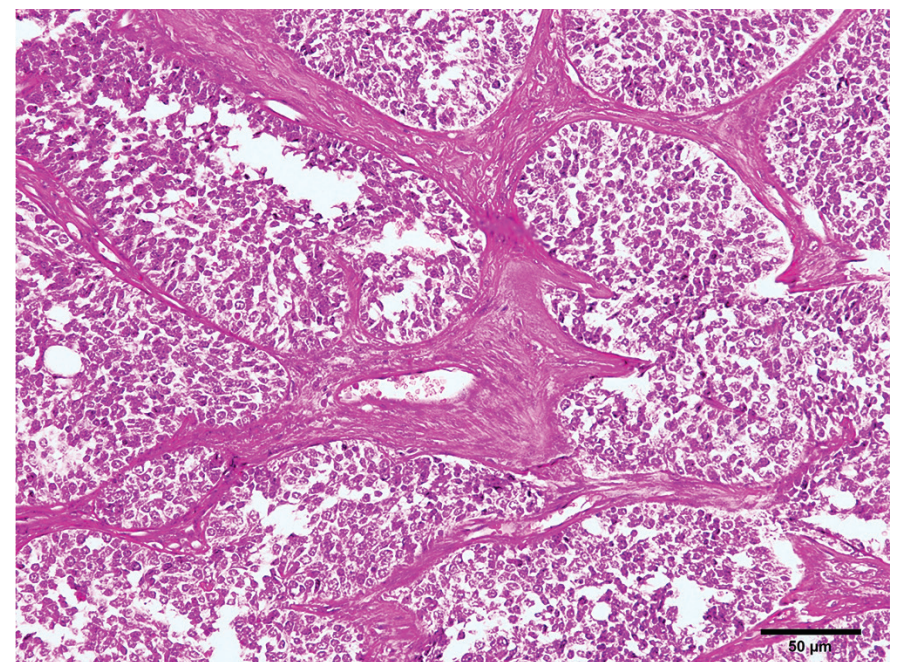

Fig.10. Intratubular and diffuse Sertoli cell tumor. Tubules of different sizes obliterated by neoplastic Sertoli cells, with rupture of the tubular basement membrane. HE, obj.20x.

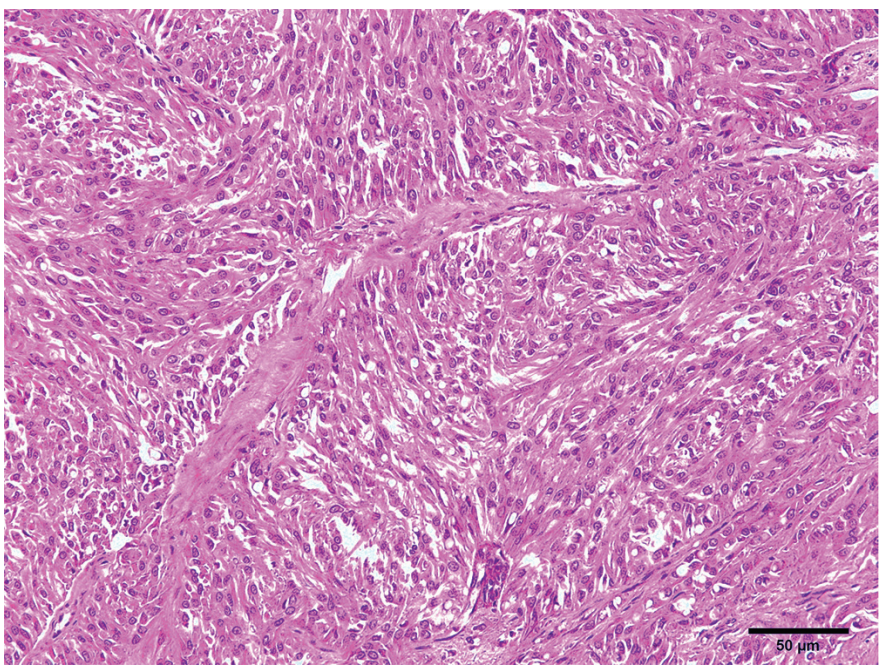

Fig.12. Diffuse Sertoli cell tumor. Entirely fusiform cell tumor. Expansive growth neoplasm with moderate desmoplastic reaction. HE, obj.20x. hypochromatic chromatin. In this arrangement, the tumors presented expansive growth, few tubule remnants, and a moderate desmoplastic reaction. Cells oriented in juxtaposition to the basement membrane were observed in some cases;

e) Neoplasms comprising vacuolated cells, with scarce eosinophilic cytoplasm, and generally intratubular pattern, with nuclei flattened by the compression of the vacuoles (Fig.13). In this arrangement, the tumors had a mild to moderate desmoplastic reaction. No malignant SCTs were observed.

\section{Leydig cell tumors (LCTs, $n=46$ )}

Most tumors (32/46) were described as nodules, single or multiple, 0.4 to $2.5 \mathrm{~cm}$ in diameter, soft, yellowish-white or

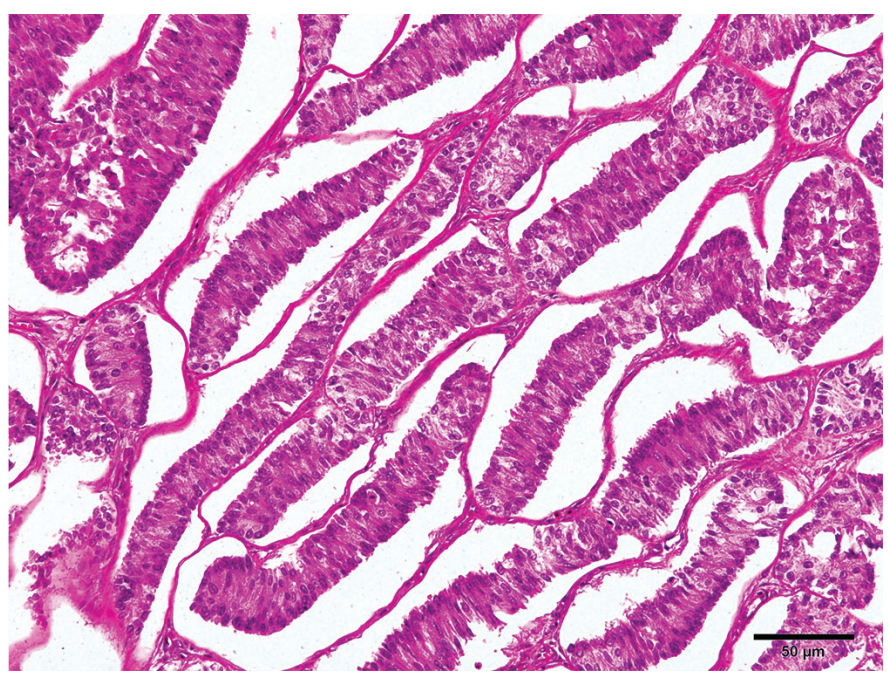

Fig.11. Intratubular Sertoli cell tumor. Columnar cells with nuclei in different positions arranged in palisades, confined to tubules of different sizes. HE, obj.20x.

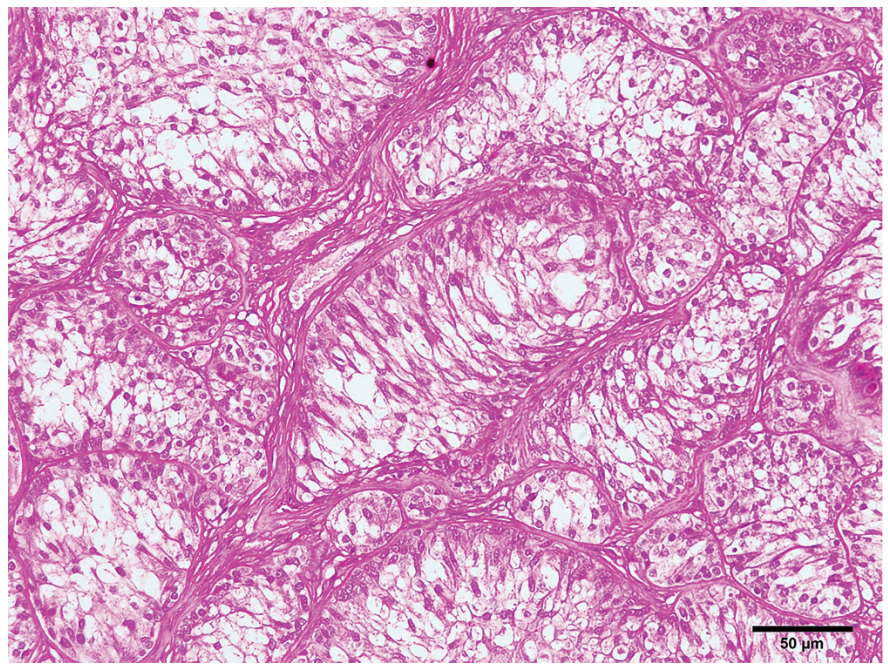

Fig.13. Intratubular Sertoli cell tumor. Neoplastic cells with intensely vacuolated cytoplasm confined to tubules of different sizes. HE, obj.20x. 
red, well delimited, and sometimes with areas of hemorrhage (Fig.14). Three LCTs formed masses ranging from 3.0 to $10 \mathrm{~cm}$ in length, with moderate to marked obliteration of the testicular parenchyma.

Under microscopy, the solid-diffuse and cystic-vascular patterns were the most commonly found, with $13 / 46$ and 12/46 cases, respectively (Fig.15). Only one dog presented a pseudoadenomatous pattern (Fig.16). In the other 20/46 animals, two or more histological patterns were observed simultaneously. Most tumors presented solid-diffuse and cysticvascular patterns, while a smaller proportion was formed by one of these patterns together with the pseudoadenomatous pattern.

Morphology of the neoplastic interstitial cells was somewhat variable. However, most tumors had polygonal cells, with eosinophilic cytoplasm, finely vacuolated, and round nuclei with condensed and hyperchromatic chromatin. Some neoplasms had cells with macrovacuoles that flattened

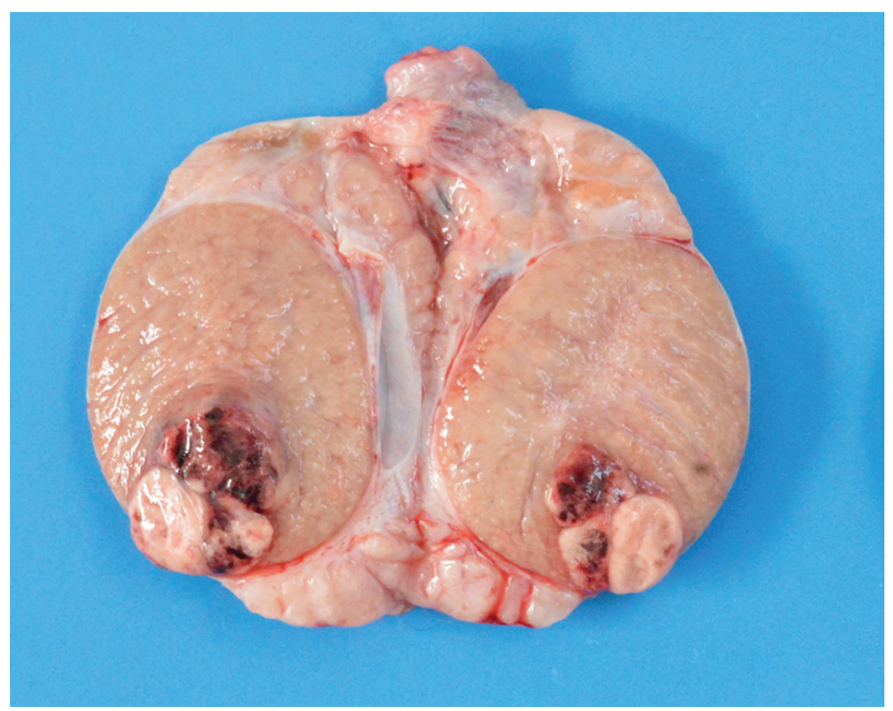

Fig.14. Leydig cell tumor. Well defined, reddish-white, soft nodule with little distortion of the testicular parenchyma.

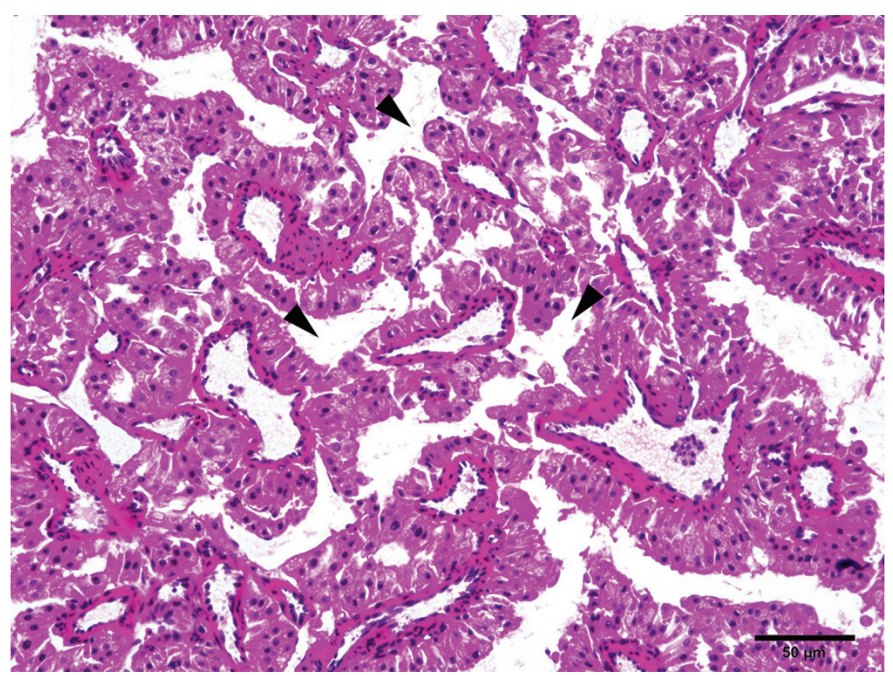

Fig.16. Pseudoadenomatous Leydig cell tumor. Neoplastic interstitial cells arranged in lobes, surrounding spaces filled with amorphous and eosinophilic fluid (arrowhead). HE, obj.20x. and displaced the nuclei peripherally, as well as cells devoid of vacuoles, usually large, polyhedral, or columnar. A high proportion of the tumors were encapsulated and had scarce fibrovascular stroma. Accumulations of hematoidin and palisade-oriented columnar cell nests surrounding blood vessels were also relatively frequent findings. One LCT of this survey was malignant. In this case, the neoplasm obliterated the testicular parenchyma and had a high mitotic index, pleomorphism, and areas of necrosis. Multiple skin and other organs metastases were observed.

\section{Mixed germ cell-sex cord stromal tumors (MGSCT, $\mathbf{n = 7 )}$}

The gross presentation of the MGSCTs varied between nodules and masses. They were single or multiple, firm, and white, 2.0 to $9.0 \mathrm{~cm}$ in length, and sometimes obliterating the testicular parenchyma (Fig.17). Microscopically, a variable degree of neoplastic germ cells interposed or surrounded by neoplastic Sertoli cells was the most characteristic

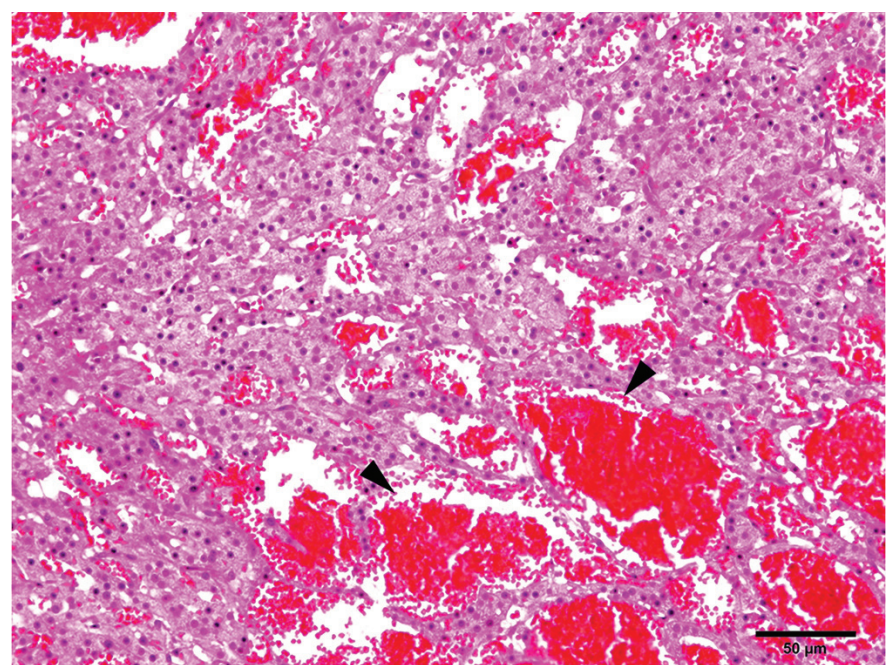

Fig.15. Cystic-vascular Leydig cell tumor. Neoplastic interstitial cells surrounding spaces filled with erythrocytes (arrowhead). HE, obj.20x.

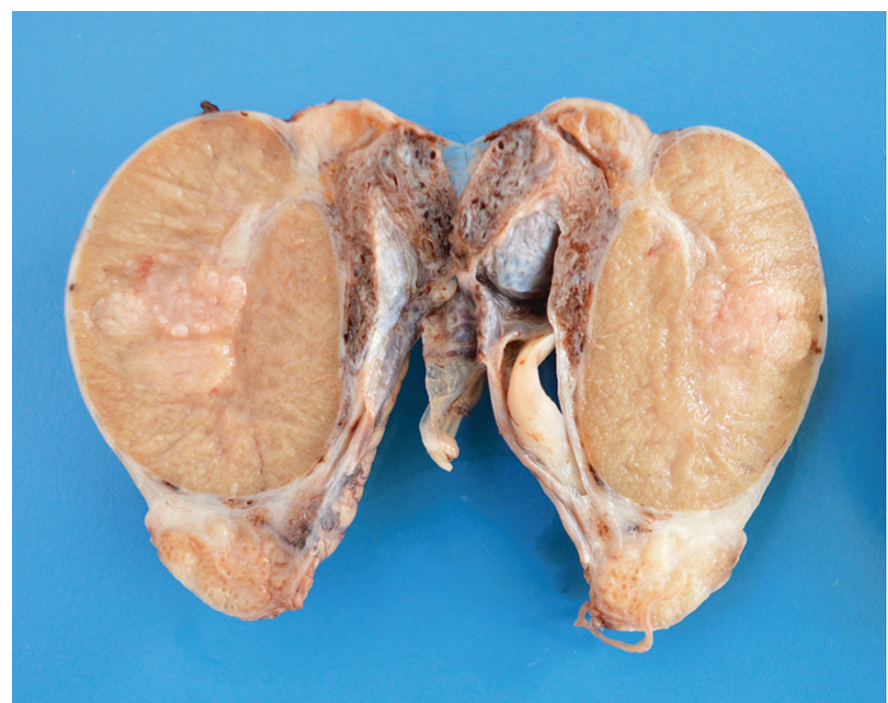

Fig.17. Mixed germ cell-sex cord stromal tumor. Focal, white, soft nodule in the center of the testicular parenchyma. 
finding in MGSCTs (Fig.18). Tubular hyalinization, moderate desmoplastic reaction, and predominance of one of the cellular components were also frequent findings. In 5/7 cases, Sertoli cells were more abundant, while $2 / 7$ cases had predominance of germ cells. In the germinative component, the cells were round or polygonal, with scarce, eosinophilic cytoplasm, and presented vesicular nuclei or finely dotted and hyperchromatic chromatin. Sertoli cells were generally fusiform, with eosinophilic cytoplasm, and oval or columnar nuclei. Mitoses were infrequent and more common in the germ component. In two cases, circular spaces with homogeneous, amorphous, hyaline and eosinophilic material, strongly positive to Periodic Acid-Schiff (PAS) staining, surrounded by Sertoli cells (Call-Exner bodies) were observed in the neoplastic formations (Fig.19). In a dog affected by malignant MGSCT, infiltration of neoplastic germ cells was observed in the lumen of blood and lymphatic vessels.

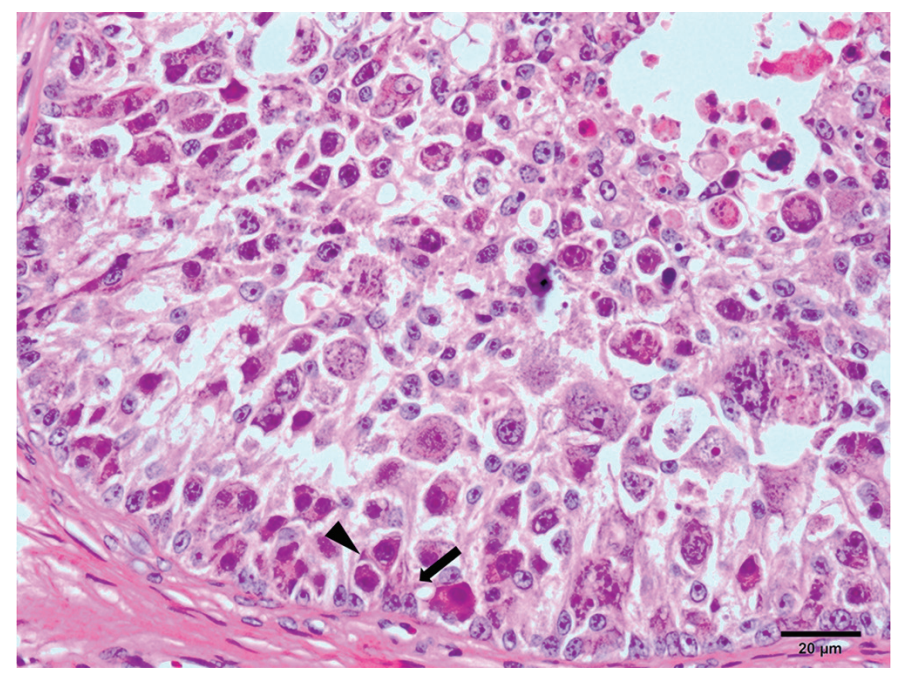

Fig.18. Mixed germ cell-sex cord stromal tumor. Neoplastic germ cells (arrowhead) interposed by neoplastic Sertoli cells (arrow). HE, obj.40x.

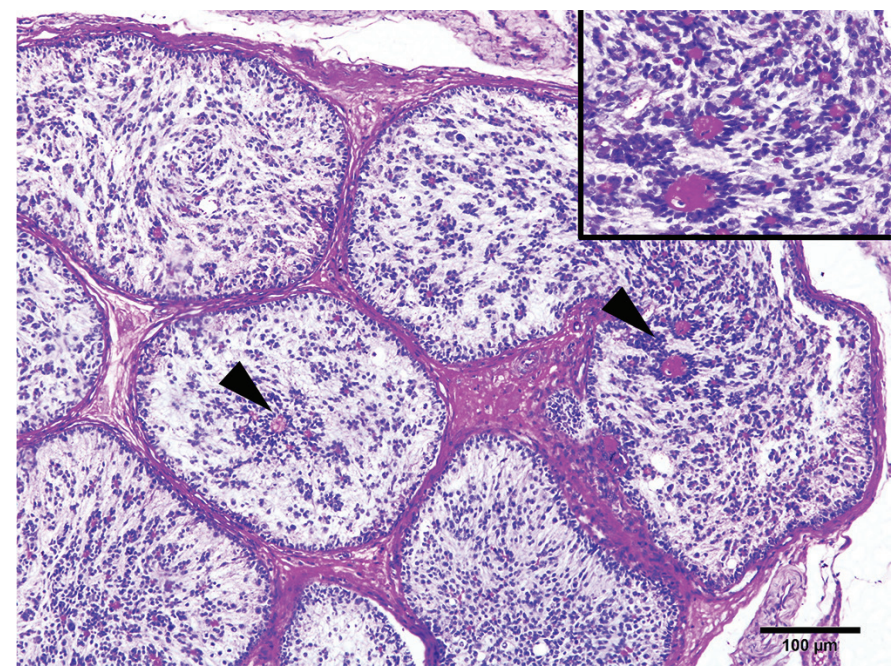

Fig.19. Mixed germ cell-sex cord stromal tumor. Call-Exner bodies (arrowhead and insert) intensely stained in pink. Periodic AcidSchiff (PAS), obj.10x.

\section{DISCUSSION}

The present study reviewed $220(10.4 \%)$ testicular tumors diagnosed among 2,118 neoplasms of male dogs. Corroborating the findings of other authors (Sapierzyński et al. 2007, Liao et al. 2009), seminomas were the most frequent neoplasms, followed by approximate proportions between LCTs and SCTs. In a study conducted in Slovenia, 206 (10.4\%) testicular tumors were diagnosed in a total of 1,975 neoplasms affecting male dogs; seminoma was the most frequent, while MGSCT was observed in a small number of dogs (Svara et al. 2014), similarly to what was observed in the present survey. However, in other studies, tumors originating from stromal elements (SCTs and/or LCTs) have been more commonly diagnosed than those from germ cells (seminomas) (Hayes \& Pendergrass 1976, Grieco et al. 2008, Argenta et al. 2016). It is worth mentioning that LCTs were the most frequently observed neoplasms in a research addressing this theme based on dog necropsies carried out in Brazil (Santos et al. 2000). Unlike what is observed in humans, where most testicular tumors originate from the germ component (Bosl \& Motzer 1997), studies conducted with dogs show variations in the frequency of different testicular neoplasms. Possible factors that would influence this variation include the origin of the samples (necropsies and/or biopsies), whether they include only clinical cases or also derived from castration (for convenience) samples, among other non-established factors.

This study allowed characterizing the 190 cases and showed that the vast majority of dogs were of defined breed (distributed in 25 breeds) and that large breeds had the most significant number of neoplasms, followed by small and medium-sized breeds. Geriatric dogs were the most affected among dogs of defined breed, followed by a high proportion of seniors. These results are only demonstrative of the group of 190 analyzed dogs, thus not allowing inference about the overall predisposition of the canine population. Some studies have described specific breeds (within small and large ones) as being at high risk for testicular neoplasms (Liao et al. 2009, Nodtvedt et al. 2010). The literature also points out that elderly dogs are prone to the development of degenerative changes in the seminiferous tubules and testicular neoplasms (James \& Heywood 1979, Lowseth et al. 1990, Santos et al. 2000).

SCT was the most frequent neoplasm, among the dogs of this study, presenting clinical signs of hyperestrogenism These findings corroborate those described by other authors, who reported that in 25 to $50 \%$ of the dogs affected by SCTs, this syndrome was characterized by symmetrical non-pruritic alopecia, hyperpigmentation, gynecomastia, galactorrhea, pendulous prepuce, and attractiveness to other male dogs (Siegel et al. 1967, Sanpera et al. 2002, Paepe et al. 2016). In one study, 65 of 318 dogs (20\%) with testicular neoplasms developed clinical signs of hormonal dysfunction (hyperestrogenism) (Cotchin 1960). It is important to note that dogs affected by the seminoma-SCT combination or by MGSCTs also manifested hyperestrogenism syndrome (feminization) in this survey, though less frequently.

Cryptorchid dogs can be up to 14.3 times more likely to develop testicular neoplasms (Ortega-Pacheco et al. 2006). More than half of the diagnosed testicular neoplasms (52/96, $54.2 \%$ ) were observed in 45 dogs with cryptorchidism (Liao et al. 2009). These results differ from those found in the present study, in which just under a quarter (51/220, 23.2\%) 
of the neoplasms occurred in 43 cryptorchid dogs. Smaller proportions of testicular neoplasms in cryptorchid dogs have also been observed by other authors (Hayes \& Pendergrass 1976). Seminomas and SCTs were the most frequent neoplasms in the 43 cryptorchid dogs assessed, corroborating some previous reports (Hayes et al. 1985, Argenta et al. 2016). The gross characteristics observed in the seminomas of this study were similar to those described in the literature (Agnew \& Maclachlan 2017).

Among dogs with seminoma, most were affected by seminomas of diffuse pattern. Conversely, studies have shown that intratubular seminomas correspond to most diagnosed seminomas (Dow 1962, Svara et al. 2014). A possible reason for this difference may lie in the type of samples analyzed (biopsy specimens and/or necropsy cases). In one of these studies (Dow 1962), many tumors had no visible lesions during necropsy, being only diagnosed under microscopy.

Two seminoma entities in humans (classic and spermatocytic) are recognized based on their histogenesis (Mostofi \& Sesterhenn 2004, Bahrami et al. 2007). In dogs, histomorphological and immunohistochemical studies show that most canine seminomas have pathogenesis similar to that of human spermatocytic seminomas (Bush et al. 2011, Thorvaldsen et al. 2012). Corroborating this hypothesis, in this study, it was possible to suggest two probable sites of neoplastic transformations based on the detailed morphological evaluation of intratubular seminomas. In these cases, most of the neoplastic transformations were observed in the center of the seminiferous tubules, originating from more differentiated germ cells, mainly spermatids. Some tumors had a layer of neoplastic cells juxtaposed to the basement membrane. In these cases, it was impossible to infer whether the neoplastic transformations originate from spermatogonia or atypical germ cells equivalent to the carcinoma in situ cells, as demonstrated by other authors (Grieco et al. 2007).

Forty-seven dogs were affected only by SCTs. High heterogeneity in cell morphology and arrangement was a frequent finding in the SCTs assessed here, regardless of the histopathological pattern (intratubular or diffuse). However, the literature presents few in-depth studies on the histological peculiarities of this neoplasm to allow its subclassification according to these cellular characteristics (Cotchin 1960, Dow 1962). Comparative studies between histomorphological characteristics such as those described here and immunohistochemical markers could be useful determining possible prognostic relevance according to the different cell types and arrangements observed in these neoplasms.

The reassessment of the LCTs in this study showed that the histological patterns (solid-diffuse, cystic-vascular, and pseudoadenomatous) recommended by the WHO (Kennedy et al. 1998) are frequently observed, and that these tumors also have some heterogeneity in cell morphology. Corroborating these findings, other authors (Cotchin 1960, Dow 1962) have observed that the cellular arrangement of some LCTs may be similar, and even confused, with those observed in SCTs. Therefore, it is crucial to bear in mind the possible variation in cell morphology and its different histological patterns, since unusual cases can be misdiagnosed. Although some immunohistochemical panels are being used to assist with diagnosing testicular neoplasms, the absence of specific immunomarkers for LCTs (Owston \& Ramos-Vara 2007) reinforces the importance of detailed morphological observation for the diagnostic accuracy of this neoplasm. In the present study, the solid-diffuse and cystic-vascular patterns were the most frequently observed, followed by a few pseudoadenomatous pattern cases. Malignant forms of LCTs have been rarely described in the literature, and are the subject of recent publications (Togni et al. 2015, Canadas et al. 2016, Kudo et al. 2019) that highlight the occurrence of metastasis, including multiple skin metastases (Canadas et al. 2016, Kudo et al. 2019). The only malignant LCT in this survey was reported in another publication (Nascimento et al. 2019).

Seven dogs were diagnosed with MGSCT in this study. Corroborating the findings by other authors, who showed that, in general, this neoplasm is uncommon in retrospective studies of canine testicular tumors (Patnaik \& Mostofi 1993, Svara et al. 2014). According to Kennedy et al. 1998, it is not known whether this neoplasm is, in fact, rare or sufficiently analyzed to be diagnosed. Only one study described some histological criteria indicative of malignancy, characterized by infiltration of germ cells in adjacent testicular structures (Patnaik \& Mostofi 1993). Some studies have used several cellular markers in the immunohistochemical characterization of these tumors. This technique has proved to be an excellent tool in diagnosing MGSCT because of its high diagnostic complexity (Owston \& Ramos-Vara 2007, Ramos-Vara \& Miller 2009, Banco et al. 2015). In the dogs reassessed in this survey, this neoplasm was characterized by varying degrees of association between neoplastic germ cells and Sertoli cells, which makes them real diagnostic challenges.

\section{CONCLUSIONS}

Through this study, it was possible to establish the prevalence $(11.2 \%)$ of dogs affected by testicular neoplasms in the region covered by the LPV-UFSM, the profile of these dogs regarding breed, breed size and age, and the prevalence $(10.4 \%)$ of testicular neoplasms among the other neoplasms affecting male dogs.

Increased testicular volume was the primary clinical sign observed and the frequency of affected cryptorchid dogs was relatively low $(23.2 \%)$.

Prevalence of different histological subtypes was established, and it was observed that malignancy characteristics were uncommon. Seminoma was the most frequently found tumor subtype, which had unusual predominance of the diffuse pattern over the intratubular pattern. Characteristics suggestive of transformation sites of neoplastic germ cells in intratubular seminomas were also observed, corroborating the hypothesis that canine seminomas possibly present pathogenesis similar to that of human spermatocytic seminomas.

LCTs and, mainly, SCTs were neoplasms with high cell morphology variation, emphasizing the importance of knowing their histomorphological variations, especially in cases with histological arrangements similar to those of these two tumors. MGSCT was an uncommon neoplasm, noting that its morphology is difficult to diagnose and that this neoplasm is characterized by varying degrees of association between neoplastic germ cells and Sertoli cells. 
Acknowledgments.- This study was financed by the "Coordenação de Aperfeiçoamento de Pessoal de Nível Superior" (CAPES), Brazil. H.H.L. Nascimento and A. Santos are CAPES doctoral fellows. E.C. Lamego and L.A.S. Tondo have undergraduate research scholarships from PROBIC-FAPERGS and A. L. Prante has an undergraduate research scholarship from PIBICCNPq. The authors would like to thank M.B. Ambrosio and L.M. Eisenhardt for their technical support.

Conflict of interest statement.- The authors declare having no conflicting interests.

\section{REFERENCES}

Agnew D.W. \& MacLachlan N.J. 2017. Tumors of the genital systems, p. 689-722. In: Meuten D.J. (Ed), Tumors in Domestic Animals. 5th ed. John Wiley \& Sons, Ames.

Argenta F.F., Pereira P.R., Caprioli R.A., Vielmo A., Sonne L., Pavarini S.P. \& Driemeier D. 2016. Neoplasia testicular em cães no Rio Grande do Sul. Acta Sci. Vet. 44:1413.

Bahrami A., Ro J.Y. \& Ayala A.G. 2007. An Overview of Testicular Germ Cell Tumors. Arch. Pathol. Lab. Med. 131(8) 1267-1280. <http://dx.doi.org/10.1043/1543-2165(2007)131[1267:A00TGC]2.0.C0;2> $<$ PMid:17683189>

Banco B., Giudice C., Ghisleni G., Romussi S., Behar D. K., \& Grieco V. 2015. Immunohistochemical Study of Mixed Germ Cell Sex Cord Stromal Tumours in 13 Canine Testes. J. Comp. Pathol. 152(2/3): 182-187. <http://dx.doi. org/10.1016/j.jcpa.2014.12.008> <PMid:25670671>

Bosl G.J. \& Motzer R.J. 1997. Testicular Germ-Cell Cancer. N. Engl. J. Med. 337(4):243-253.<http://dx.doi.org/10.1056/NEJM199707243370406> <PMid:9227931>

Bush J.M., Gardiner D.W., Palmer J.S., Meyts R.D. \& Veeramachaneni D.N.R. 2011. Testicular germ cell tumours in dogs are predominantly of spermatocytic seminoma type and are frequently associated with somatic cell tumours. Int. J. Androl. 34(4pt2):288-295. <http://dx.doi.org/10.1111/j.1365-2605.2011.01166.x><PMid:21615421>

Canadas A., Romão P. \& Gartner F. 2016. Multiple cutaneous metastasis of a malignant leydig cell tumour in a Dog. J. Comp. Pathol. 155(2/3):181184. <http://dx.doi.org/10.1016/j.jcpa.2016.05.012><PMid:27392423>

Cotchin E. 1960. Testicular neoplasms in dogs. J. Comp. Pathol. Ther. 70:232-248. <http://dx.doi.org/10.1016/s0368-1742(60)80024-0><PMid:13812261>

Dow C. 1962. Testicular tumours in the dog. J. Comp. Pathol. Ther. 72:247-265.

Folge B. 2009. Guia Ilustrado Zahar: cães. 2nd ed. Zahar, Rio de Janeiro, p. $52-261$.

Gardner M. 2017. Geriatrics and Fragility. p. 18-19. In: Gardner M. \& McVety D. (Eds), Treatment and Care of the Geriatric Veterinary Patient. 1st ed. John Wiley \& Sons, Hoboken.

Gould M.K., Fletcher J., Iannettoni M.D., Lynch W.R., Midthun D.E., Naidich D.P. \& Ost D.E. 2007. Evaluation of patients with pulmonary nodules: when is it lung cancer? ACCP Evidence-Based Clinical Practice Guidelines (2nd Edition). Chest J. 132(3):108S-130S. <http://dx.doi.org/10.1378/ chest.07-1353><PMid:17873164>

Grieco V., Riccardi E., Greppi G.F., Teruzzi F., Iermano V. \& Finazzi M. 2008. Canine testicular tumors: a Study on 232 dogs. J. Comp. Pathol. 138(2/3):8689. <http://dx.doi.org/10.1016/j.jcpa.2007.11.002><PMid:18295787>

Grieco V., Riccardi E., Rondena M., Ciampi V. \& Finazzi M. 2007. Classical and spermatocytic seminoma in the dog: histochemical and immunohistochemical findings. J. Comp. Pathol. 137(1):41-46. <http://dx.doi.org/10.1016/j. jcpa.2007.03.009><PMid:17629966>

Hayes H.M. \& Pendergrass T.W. 1976. Canine testicular tumors: epidemiologic features of 410 dogs. Int. J. Cancer. 18(4):482-487. <http://dx.doi.org/10.1002/ijc.2910180413><PMid:977190>
Hayes H.M., Tarone R.E., Casey H.W. \& Huxsoll D.L. 1990. Excess of seminomas observed in Vietnam Service U.S. military working dogs. J. Natl. Cancer Inst. 82(12):1042-1046. <http://dx.doi.org/10.1093/jnci/82.12.1042> <PMid:2348468>

Hayes H.M., Wilson G.P., Pendergrass T.W. \& Cox V.S. 1985. Canine cryptorchism and subsequent testicular neoplasia: case-control study with epidemiologic update. Teratology. 32(1):51-56. <http://dx.doi. org/10.1002/tera.1420320108> <PMid:2863879>

James R.W. \& Heywood R. 1979. Age-related variations in the testes and prostate of beagle dogs. Toxicology. 12(3):273-279. <http://dx.doi. org/10.1016/0300-483x(79)90073-8><PMid:494308>

Kennedy P.C., Cullen J.M., Edwards J.F., Goldschmidt M.H., Larsen S., Munson L. \& Nielsen S. 1998. Histological classifications of tumors of the genital system of domestic animals, p.17-18. In: World Health Organization International Histological Classification of Tumors of Domestic Animals, Vol. IV, Armed Forces Institute of Pathology. Washington D.C.

Kesley J.L., Moore A.S. \& Glickman L.T. 1998. Epidemiologic studies of risk factors for cancer in pet dogs. Epidemiol. Rev. 20(2):204-217. <http://dx.doi.org/10.1093/oxfordjournals.epirev.a017981><PMid:9919439>

Kudo T., Kamiie J., Aihara N., Doi M., Sumi A., Omachi T. \& Shirota K. 2019. Malignant Leydig cell tumor in dogs: two cases and a review of the literature. J. Vet. Diagn. Invest. 31(4):557-561. <http://dx.doi. org/10.1177/1040638719854791><PMid:31248354>

Liao A.T., Chu P.Y., Yeh L.S., Lin C.T. \& Liu C.H. 2009. A 12-Year Retrospective study of canine testicular tumors. J. Vet. Med. Sci. 71(7):919-923. <http://dx.doi.org/10.1292/jvms.71.919> <PMid:19652479>

Lowseth L.A., Gerlach R.F., Gillett N.A. \& Muggenburg B.A. 1990. Age-related changes in the prostate and testes of the Beagle dog. Vet. Pathol. 27(5):347353.<http://dx.doi.org/10.1177/030098589002700507><PMid:1700534>

MacLachlan N.J. \& Kennedy P.C. 2002. Tumors of the genital system, p. 547574. In: Meuten D.J. (Ed). Tumors in Domestic Animals, 4th ed. A Blackwell Publishing Company, Ames.

Madewell B.R. 1981. Neoplasms in domestic animals: A review of experimental and spontaneous carcinogenesis. Yale. J. Biol. Med. 54(2):111-125. $<$ PMid:7269640>

Mostofi F.K. \& Sesterhenn I.A. 2004. Tumours of the Testis and Paratesticular Tissue, p.232-235. In: Eble J.N., Sauter G., Epstein J.I. \& Sesterhenn I.A. (Eds), World Health Organization Classification of Tumours. Pathology and Genetics of Tumours of the Urinary System and Male Genital Organs. IARC Press, Lyon.

Nascimento L.H.H., Tochetto C., Lucena B.R., Kommers G.D. 2019 Testicular Interstitial Cell Tumor with Disseminated Cutaneous Metastasis in a Dog. Acta Sci. Vet. 47(supl.1):434. <http://dx.doi.org/10.22456/1679-9216.96391>

Nielsen S.W. \& Lein D.H. 1974. Tumours of the testis. B. World Health Organ. 50(1/2):71-78. <PMid:4547653>

Nodtvedt A., Gamlem H., Gunnes G., Grotmol T., Indrebo A. \& Moe L. 2010. Breed differences in the proportional morbidity of testicular tumours and distribution of histopathologic types in a population-based canine cancer registry. Vet. and Comp. Onco. 9(1):45-54. <http://dx.doi. org/10.1111/j.1476-5829.2010.00231.x><PMid:21303453>

Ortega-Pacheco A., Rodriguez-Buenvil J.C., Segura-Correa J.C., BolioGonzalez M.E., Jiménez-Coello M. \& Linde Forsberg C. 2006. Pathological conditions of the reproductive organs of male stray dogs in the tropics: prevalence, risk factors, morphological findings and testosterone concentrations. Reprod. Domest. Anim. 41(5):429-437. <http://dx.doi. org/10.1111/j.1439-0531.2006.00688.x> <PMid:16984349>

Owston M.A. \& Ramos-Vara J.A. 2007. Histologic and immunohistochemical characterization of a testicular mixed germ cell sex cord-stromal tumor and a leydig cell tumor in a dog. Vet. Pathol. 44(6):936-943.<http://dx.doi. org/10.1354/vp.44-6-936> <PMid:18039910> 
Paepe D., Hebbelinck L., Kitshoff A. \& Vandebeele S. 2016. Feminization and severe pancytopenia caused by testicular neoplasia in a cryptorchid dog. Vlaams Diergen Tijds. 85(4):197-205. <http://dx.doi.org/10.21825/vdt. v85i4.16329>

Patnaik A.K. \& Mostofi F.K.A. 1993. A Clinicopathologic, histologic, and immunohistochemical study of mixed germ cell-stromal tumors of the testis in 16 Dogs. Vet. Pathol. 30(3):287-295. <http://dx.doi. org/10.1177/030098589303000310><PMid:8392765>

Ramos-Vara J.A. \& Miller M.A. 2009. Immunohistochemical Evaluation of Gata-4 Canine Testicular Tumors. Vet. Pathol. 46(5):893-896. <http:// dx.doi.org/10.1354/vp.08-VP-0287-R-BC> <PMid:19429994>

Reis-Filho J.S., Ricardo S., Gärtner F. \& Schmitt F.C. 2004. Bilateral gonadoblastomas in a dog with mixed gonadal dysgenesis. J. Comp. Pathol. 130(2/3):229233. <http://dx.doi.org/10.1016/j.jcpa.2003.09.010><PMid:15003485>

Sanpera N., Masot N., Janer M., Romeo C. \& Pedro R. 2002. Oestrogen-induced bone marrow aplasia in a dog with a sertoli cell tumour. J. Small Anim. Pract. 43(8):365-369. <http://dx.doi.org/10.1111/j.1748-5827.2002. tb00087.x><PMid:12201446>

Santos R.L., Silva C.M., Ribeiro A.F.C. \& Serakides R. 2000. Testicular tumors in dogs: frequency and age distribution. Arq. Bras. Med. Vet. Zoo. 52(1):25-26. <http://dx.doi.org/10.1590/S0102-09352000000100007>
Sapierzyński R., Malicka E., Bielecki W., Krawier M., Osinska B., Sendecka H. \& Sobczak-Filipiak M. 2007. Tumors of the urogenital system in dogs and cats. Retrospective review of 138 cases. Pol. J. Vet. Sci. 10(2):97-103. <PMid:17882933>

Siegel E.T., Forchielli E., Dorfman R.I., Brodey R.S. \& Prier J.E. 1967. An estrogen study in the feminized dog with testicular neoplasia. Endocrinology, 80(2):272-277. <http://dx.doi.org/10.1210/endo-80-2-272>

Svara T., Gombac M., Pogorevc E., Plavec T., Zrimsek P. \& Pogacnik M. 2014. A retrospective study of canine testicular tumour in Slovenia. Slov. Vet. Res. 51(2):81-88. <http://dx.doi.org/10.13140/2.1.1966.9123>

Thorvaldsen T.E., Nodtvedt A., Grotmol T. \& Gunnes G. 2012. Morphological and immunohistochemical characterisation of seminomas in Norwegian dogs. Acta Vet. Scand. 54(1):52. <http://dx.doi.org/10.1186/1751-0147-54-52> $<$ PMid:22986090>

Togni A., Rutten M., Rohrer Blei C. \& Hurter K. 2015. Metastasized leydig cell tumor in a dog. Schweiz. Arch. Tierheilkd. 157(2):111-115. <http://dx.doi.org/10.17236/sat00010><PMid:26753337>

Yates D., Hayes G., Heffernan M. \& Beynon R. 2003. Incidence of cryptorchidism in dogs and cats. Vet. Rec. 152(16):502-504.<http://dx.doi.org/10.1136/ vr.152.16.502><PMid:12733559> 